\title{
Effectiveness of Teachers at Preparing Grade 7 Candidates for Environmental Science Examinations
}

\author{
Takawira Kazembe ${ }^{*}$ and Methias Sithole \\ Department of Science and Maths Education, University of Zimbabwe, P. O. Box MP167, Harare, Zimbabwe
}

Received 13 February 2010 - Accepted 09 September 2010

\begin{abstract}
The study was undertaken to investigate the low Grade 7 pass rate at Primary Schools in Zimbabwe which averaged 75\% for local languages, $47 \%$ for General Paper (GP) and 40\% for Maths. The low GP pass rate was thought to be due to teachers' attitudes towards developing scientific skills necessary to understand Environmental Science (ES). A sample of 77 student teachers, 7 lecturers, 3 headmasters and 12 mentors was used to probe how teachers are trained to teach ES. A questionnaire, observations, documents and informal interviews were used to collect data from student teachers. Interviews were used to collect data from lecturers, mentors and headmasters. About 3.9\% of student teachers found science apparatus difficult to use because they were not adequately trained to handle them. At least $50 \%$ of them believe that practical activities are necessary for theory comprehension and use practical exercises to motivate pupils so that they achieve their maximum potential. However, most student teachers lament the unavailability of teaching aids although some of them were not keen on their improvisation notwithstanding their necessity for promotion of hands-on minds-on activities. Lecturers attributed students' problems to students' insufficient knowledge about ES educational attitudes and blamed this on overloading of students with content at the expense of developing scientific skills. The mentors admitted having insufficient knowledge and skills to adequately supervise student teachers, and that the unavailability of textbooks caused them to engage on drilling methods because headmasters emphasized on high pass rate but were silent on meaningful learning. They believed that ES practical activities were not necessary for Grade 7 examinations.
\end{abstract}

Key words: Environmental Science, Hands-on minds-on, Primary Schools, Lesson Observation, Intervention Strategies

\section{Introduction}

A decline in student achievement in the Grade 7 Examinations has been blamed on the absence of a link between student activities and conceptual development leading to the students' failure to develop scientific skills (Shumba, 1997). High pass rates are only realized in local languages: Ndebele and Shona: 75\%; compared with English: 57\% and General Paper: $47 \%$ and Mathematics: $40 \%$. The contribution of Environmental Science (ES) to low pass rate is high. Attitudes affect teaching and learning of science subjects and influence achievement (Simpson, 1978; Matsikidze, 1994) and prior experiences in a subject area influence future learning experiences in that area (Ausubel, 1963; -1968; Simpson, 1978; Novak 2000). Student teachers rarely apply hands-on minds-on teaching techniques during teaching practice (Shumba, 1997). It thus became attractive to probe the failure of Grade 7

\footnotetext{
*Correspondence Author: Phone: 26304 303211; Fax: 26304333407 E-mail: kazembetc@yahoo.co.uk

ISSN: 1306-3049, (C)2010
} 
candidates in ES through an investigation of how the teachers who teach the subject are trained.

\section{Research questions:}

1. What attitudes do student teachers have towards ES?

2. How do the different attitudes affect the student teachers' learning and later on the way they will teach ES to their own students?

3. What intervention strategies can be used to enhance learning and teaching of ES?

\section{Method}

The effect of attitude on how student teachers learn ES may be understood after investigating how student teachers, college lecturers, headmasters, and mentors perceive the manner in which the subject is being taught and learnt at college and at the schools. A qualitative paradigm, which studies things in their natural settings, will be used to investigate attitudes of all participants and would help explain the results of the quantitative paradigm which will be used to study the outcomes of teaching at college (Lincoln and Guba, 1985; Borg and Gall, 1989; Bogdan and Biklen, 1992; Best and Khan, 1993; Mhlanga and Ncube, 2003; Chikuni, 2005).

\section{Sample}

The study employed convenience sampling and random sampling. All 77 student teachers who were on teaching practice and all the ES lecturers at the teacher training college, mentors and headmasters at selected primary schools in Manicaland Province, 2007, took part in the study. The student teachers responded to a questionnaire and had their teaching practice documents inspected. Four student teachers ( 2 male $\& 2$ female) were randomly sampled for lesson observation. Two male students were randomly sampled by assigning numbers to all male students. As each number was picked, it was replaced to allow all participants an equal chance of being picked (Yin, 1989; Borg and Gall, 1996; Mhlanga and Ncube, 2003:56). Similarly, two female students were randomly selected. All headmasters of the primary schools in the province were given numbers and 3 were randomly selected as for students, above. Similarly, 12 mentors were selected and included as participants. Thus, the sample consisted of 77 student teachers, 7 lecturers, 3 headmasters and 12 class mentors. Data were collected from student teachers through questionnaires, observation, documents and informal interviews, and structured and unstructured interviews were used to collect data from lecturers, headmasters and class mentors, consistent with Lincoln and Guba (1985) and Best \& Khan (2003).

\section{Pre-test}

A pilot study was carried out at Chikanga Primary School, Mutare, to check on the efficacy and manageability of the instruments before the study began (Tuckman, 1978; Gall et. al., 1996; Gay, 1996). Only 2 student teachers filled in the questionnaires; 2 mentors, the headmaster and 3 college lecturers were interviewed; and 1 lesson observation was made. The pilot study led to some fine tuning on the instruments adapted from Matsikidze (1994) and Shumba (1999).

\section{The Questionnaire}

Student teachers' questionnaire instruments were built in such a way that quantitative data could be reached in specified categories (Gatawa, 1990). A questionnaire was 
administered to this large group of participants because face-to-face interactions with each respondent would have been time consuming. The questionnaire sought student teachers' perception of issues related to strategies in teaching of ES; interest in preparing materials; enjoyment in carrying out practical activities such as use of local environment in teaching ES and whether the level of staff development during residential courses enhances implementation of theory. The questionnaires were handed to student teachers when one of the researchers visited schools and when student teachers visited the college for mid-term consultations, achieving a 100\% return.

\section{The interview}

One interview was conducted with each of the 7 lecturers, 12 class mentors and 3 headmasters, asking both structured and unstructured questions, focusing on interventions and pedagogical issues (Appendices 1, 2 \& 3). Informal interviews were held with student teachers to get their views on intervention strategies (Worthen and Sanders, 1987).

The headmasters' and mentors' interviews were held during the time one of the researchers was on teaching practice assessment visits. The headmasters were interviewed in their offices; the mentors were interviewed in their classrooms; and the college lecturers were interviewed in their offices at the college, all providing varied perceptions of attitudes.

\section{Lesson observation}

One of the researchers observed each of 4 student teachers teaching ES during a 30minute period, using a lesson observation schedule(Appendix 4) prepared in order to investigate what actually happens in the classroom situation so that a first hand record of attitudes in a classroom setting would be captured (Stenhouse, 1975; Borg and Gall, 1985; Macleod, 2000). The instrument was meant to measure the extent to which student teachers implemented strategies and approaches taught to them at college. It focused on how student teachers interacted with pupils, capturing pupil motivation, classroom environment and climate, respect for cultural values, pupils' feelings and the skills pupils acquired (Marshall and Rossman, 1999) and on whether the student teachers promoted hands-on mind-on activities.

\section{Documents}

Records of pupils' written work and student teachers' schemes of work; detailed lesson plans and marks scored by student teachers during lesson observations by college lecturers were examined. This assisted the researchers to have an idea of the extent to which students' attitudes were related to what they had been taught. The exercise also verified student teachers' claims concerning their ability to motivate pupils, use of correct teaching techniques and exact pupils' performance as indicated by scores in the exercise books (Stenhouse, 1975; Borg and Gall, 1985; Ary et. al., 1990; Macleod, 2000).

\section{Data analysis}

Data obtained from the lecturers, headmasters and mentors about student teachers' attitudes towards ES were checked against students' documents and responses in order to get a complete picture of what was going on (Magagula, 1995; Nyawaranda, 1997).

\section{Questionnaire}

Data were arranged into frequency distributions, and presented in tabular and graphical forms. The tallying system was used to determine the frequency of common responses. All 
data involving opinion ratings were processed by way of frequency and computing responses into percentages when numbers were large enough to justify such treatment. The responses were then quantitatively analyzed so that any pattern of data could be determined. For qualitative data, reasons and justifications were indicated as given by respondents. Responses were then summarized and placed under the relevant category.

\section{Interviews}

Interview sets were first transcribed verbatim, then summarized and grouped, establishing patterns. Those that illustrated specific patterns were summarized in the written report, giving a statistical analysis suitable for data interpretation. Descriptive statistical methods are advantageous in that they enable the researcher to organize, describe and summarize observations, making it relatively easy to interpret data (Chivore, 2005).

\section{Observations and documents}

Observations of lessons were coded in terms of presence or absence of specific student teacher attitudes. These were later expressed as frequencies across observations. Notes made during lesson observation were summarized, grouped into classes, and patterns across classes were noted. The results of the 4 lesson observations were then pooled together by way of frequencies and percentages.

\section{Student specialization \& work loads}

The whole population of 77 student teachers (46\% female and 54\% male) participated in the study. Some of them enrolled after O-level (89.6\%) and the other 10.4\% had A-level qualifications. Their subject specializations at the college were as follows: ES (35.1\%), Maths (9.9\%), Shona (7.8\%), English (3.9\%), Social Studies (7.8\%), Religious and Moral Education (10.4\%), Art and Design (7.8\%), Music (7.8\%), Home Economics (3.9\%), and Physical Education (6.5\%). All the student teachers receive identical ES teaching methodologiestuition.

The majority of the students (72.7\%) taught 2 periods per week, whilst $7.8 \%$ taught 1 period per week, 3.9\% taught 3 periods per week, and 10.4\% taught more than 3 periods per week. ES was allocated more than 3 periods of 30 minute duration at $84.4 \%$ of the schools where the participants were stationed, with $28.0 \%$ of the headmasters being science specialists, the balance being arts.

\section{Enjoyment of practical activities, Table 1.}

Enjoyment of a subject influences the minds and feelings of learners towards it (Simpson, 1978; Travers et. al., 1993). The student teachers (95\%) said that they enjoyed teaching ES because it is their area of specialization and because ES enables learners to understand the world they live in. About $90 \%$ of student teachers expressed their desire to spend more time teaching ES to assist learners understand their environment. About $74 \%$ of them believed that practical work should be done even when theory was explained well. Practical activities enhance understanding and theory alone cannot fully develop a pupil's ability to grasp ES concepts. At least $85 \%$ of them look forwards to ES practical sessions, since ES activities are enjoyable and bring liveliness to learning.

They emphasized the importance of enjoying ES activities, an important factor in determining attitudes towards ES. Thus, in agreement with Simpson (1978) and Travers et al. (1993) who observed that enjoyment of a subject influences the minds and feelings a learner has toward the subject. The results of lesson observation also indicate that the methodology 
used to teach ES is short of hands-on minds-on. Hands-on methods are motivational since they generate enthusiasm, excitement, and enjoyment and because they make students become actively involved in learning (Wesson, Wilson and Mandlebaum, cited in Gay, 1996).

Table 1. Student teachers' attitude towards ES practical work

\begin{tabular}{|c|c|c|c|c|c|}
\hline Question & & AM & $\mathbf{U}$ & $\mathbf{D M}$ & DS \\
\hline 11. Enjoying teaching ES & 79.2 & 15.6 & 2.6 & 2.6 & 0.0 \\
\hline $\begin{array}{l}\text { 12. Spending extra time teaching. Available ES is not } \\
\text { sufficient. }\end{array}$ & 48.1 & 41.6 & 2.6 & 3.9 & 3.9 \\
\hline 17. ES activities doing more harm than good & 1.3 & 9.1 & 3.9 & 14.3 & 71.4 \\
\hline 19. Always look forward to ES practical activities. & 54.5 & 31.2 & 2.6 & 6.5 & 5.2 \\
\hline $\begin{array}{l}\text { 20. To learn in a scientific manner one needs to study the } \\
\text { writings of great scientists }\end{array}$ & 9.1 & 14.3 & 17.2 & 26.6 & 28.6 \\
\hline $\begin{array}{l}\text { 21. ES practical activities are too involving so I enjoy } \\
\text { discussion. }\end{array}$ & 37.7 & 18.2 & 11.7 & 15.6 & 22.1 \\
\hline $\begin{array}{l}\text { 23. Enjoy supervising fast learners during ES practical } \\
\text { activities. }\end{array}$ & 13.0 & 7.8 & 50.2 & 44.2 & 29.9 \\
\hline $\begin{array}{l}\text { te: AS = agree very strongly; } \\
\text { M = disagree mildly; }\end{array}$ & & & & d; & \\
\hline
\end{tabular}

Responses are reported as percentages of respondents.

Attitude towards ES practical work, Table 2.

Student teachers improvised apparatus for practical work because appropriate equipment was not always readily available. They resorted to improvisation because they believe that experimentation enhances understanding of concepts. Shortages force pupils to share equipment and materials most of the time during ES practical sessions. However, 20.8\% of the student teachers do not believe that practical work enhances pupils' acquisition of science concepts. Some of these (3.9\%) admitted that they often found science apparatus difficult to use because they were not sufficiently trained to handle apparatus. The majority of student teachers (88.3\%) indicated that they enjoy assisting pupils with difficulties in ES. Those who did not indicated that they never have time to help pupils whose cultural beliefs conflict with ES, thus, contradicting Pafunwa (1972) and Kasambira (1993) who proposed that adequate experience with materials and phenomena of the physical world should be provided to all children.

Table 2. Student teachers' attitude towards ES practical work

\begin{tabular}{|c|c|c|c|c|c|}
\hline Question & VO & $\mathbf{O}$ & SO & $\mathbf{S}$ & AN \\
\hline $\begin{array}{l}\text { 37. Have improvised equipment in order to do ES practical } \\
\text { work }\end{array}$ & 53.2 & 15.6 & 24.7 & 6.5 & 0.0 \\
\hline 41. Cannot see the point of doing many experiments. & 6.5 & 7.8 & 19.5 & 15.6 & 46.8 \\
\hline 45. Use group ES practical work & 46.8 & 31.2 & 16.9 & 3.9 & 1.3 \\
\hline $\begin{array}{l}\text { 47. ES practical work hardly enhances acquisition of } \\
\text { concepts learnt during theory lessons }\end{array}$ & 14.3 & 11.7 & 29.9 & 15.6 & 28.6 \\
\hline 51. Finding a lot of apparatus difficult to use & 3.9 & 0.0 & 28.5 & 44.3 & 23.3 \\
\hline $\begin{array}{l}\text { 54. Assist pupils with different cultural values and beliefs } \\
\text { in ES }\end{array}$ & 49.4 & 19.5 & 16.9 & 3.9 & 10.4 \\
\hline
\end{tabular}

Note: $\mathrm{VO}=$ Very often; $\quad \mathrm{O}=$ often; $\quad \mathrm{SO}=$ sometimes; $\mathrm{S}=$ seldom; $\mathrm{AN}=$ almost never. Responses are reported as percentages of respondents. 
Student teachers' views on motivation and ability to motivate pupils, Table 3.

Most student teachers felt the need to help all pupils, whether they are slow or fast learners. They go round the class assisting pupils with learning difficulties and argue that even fast learners need assistance. They go round the class to facilitate learning; to maintain order during the learning process; and they enjoy monitoring pupils' practical activities. They give clear instructions before and during ES activities, communicate supportive feelings to pupils and demonstrate love for ES to ensure that pupils do the right things, and they believe that motivation of pupils is a teaching requirement. Such a teacher is taking heed of observations by Simpson (1978) and Gay (1996) that a teacher who fails to understand pupils increases the probability that some pupils end up fearing and disliking the subject.

Table 3. Student teachers' ability to motivate pupils $(\mathrm{N}=77)$

\begin{tabular}{lllllc}
\hline Question & AS & AM & U & DM & DS \\
\hline $\begin{array}{l}\text { ES practical activities should be done with only slow } \\
\text { learners. }\end{array}$ & 7.9 & 3.9 & 0.0 & 6.5 & 72.7 \\
\hline $\begin{array}{l}\text { 22. Getting round the whole class during ES practical } \\
\text { activities. }\end{array}$ & 62.3 & 20.8 & 3.9 & 5.2 & 7.8 \\
\hline $\begin{array}{l}\text { 34. Pupils have enjoyed ES practical work } \\
\text { 43. Teacher provides clear instructions during ES activities. }\end{array}$ & 50.6 & 31.2 & 15.6 & 2.6 & 0.0 \\
\hline
\end{tabular}

Note: $\mathrm{AS}=$ agree very strongly; $\quad \mathrm{AM}=$ agree mildly; $\quad \mathrm{U}=$ undecided;

$\mathrm{DM}=$ disagree mildly; $\quad$ DS = disagree strongly.

Responses are reported as percentages of respondents.

\section{Classroom environment, Table 4.}

About $49 \%$ of the student teachers indicated that it was rarely possible to properly teach ES theory independently of experiments, although practical activities were sometimes left out because of shortages of time and equipment. 87\% indicated that the classrooms were often too crowded for some practical activities which needed large space. About $51 \%$ of them believed that pupils enjoyed ES practical work which verifies theoretical concepts. However, 49\% believed that pupils are rarely given sufficient time to explore the environment, except in activities that are meant to prepare them for examinations. A larger number, however, still claimed that they often give practical exercises often to motivate pupils and the pupils often ask for help when they fail to follow instructions. At times the failure to follow instructions will be due to lack of concentration because of the crowding that leads to classrooms being very hot and stuffy. The students were consistent with Bates (1978) in their support for good classroom environment. Bates argued that students' satisfaction with class work is highly correlated with several characteristics of the learning environment. They are also consistent with the findings of Shumba (1998) who castigated classroom environments in which the majority of pupils never ask questions, never sought clarification of learning points, and rarely had opportunity to give answers or explain something. 
Table 4. Effect of classroom environment on attitude $(\mathrm{N}=77)$

\begin{tabular}{|c|c|c|c|c|c|}
\hline Question & VO & $\mathbf{O}$ & SO & $\mathbf{S}$ & AN \\
\hline 24. Regular ES class is unrelated to practical activities & 7.8 & 16.9 & 26.0 & 10.4 & 39.0 \\
\hline 25. ES class is crowded when doing practical activities. & 22.1 & 13.0 & 39.0 & 13.0 & 13.0 \\
\hline 34. Pupils have enjoyed ES practical work. & 50.6 & 31.2 & 15.6 & 2.6 & 0.0 \\
\hline $\begin{array}{l}\text { 40. Classroom has enough room for individual practical } \\
\text { work. }\end{array}$ & 9.1 & 11.7 & 16.9 & 15.6 & 46.8 \\
\hline 42. Classroom is hot and stuffy. & 15.6 & 13.2 & 31.2 & 13.0 & 27.3 \\
\hline 49. ES activities prepare pupils for their final examinations. & 51.9 & 27.3 & 13.0 & 6.5 & 1.3 \\
\hline $\begin{array}{l}\text { 52. Pupils prefer to do experiments on their own, not in } \\
\text { groups. }\end{array}$ & 3.9 & 2.6 & 45.5 & 18.2 & 29.9 \\
\hline 55. Making pupils feel good about themselves. & 58.4 & 26.0 & 14.3 & 1.3 & 0.0 \\
\hline $\begin{array}{l}\text { 56. Pupils asking me for help are convinced that I really } \\
\text { understand their feelings }\end{array}$ & 61.0 & 23.4 & 14.3 & 1.3 & 0.0 \\
\hline $\mathrm{O}=$ often; $\quad \mathrm{SO}=$ sometime & & ld & & & \\
\hline
\end{tabular}

\section{Creation of a good ES classroom climate, Table 5.}

The students go on teaching practice after receiving comprehensive lessons on Education Foundations and Pedagogics, hence they will be aware of the importance of good classroom climate. Attitudes are influenced by the climate teachers create and this affects students' achievement. A friendly surrounding is one where love for science is demonstrated; a classroom where the atmosphere between the teacher and the students is conducive to attainment of the learning goals; students are carefully listened to; respect is given to young people; pupils are allowed to question and learn in a relatively informal atmosphere; pupils are minimally controlled and well organized (Simpson, 1978; Kyriacou, 1986; Majasan; 1995).

The student teachers claimed that pupils learn fast if they watch others doing activities. Pupils depend on each other very often and they are always observed consulting one another. However, since pupils learn at different rates, grouping them sometimes leads to difficulties of supervision to ensure safety and proper use of time. 54\% of the student teachers indicated that pupils work co-operatively during ES practical work when fast learners assist the slow ones. The pupils who never question why some practical exercises do not give the expected results do so because they lack sufficient vocabulary and background information and their learning abilities are below the expected grade level. However, the student teachers said that pupils often explore their own ES interest as the guided learning does not stop them from doing their own things. 
Table 5. Frequency student teachers create a good ES classroom climate $(\mathrm{N}=77)$

\begin{tabular}{llllll}
\hline Question & VO & $\mathbf{O}$ & SO & S & AN \\
\hline $\begin{array}{l}\text { 27. Different pupils collect different data for the same } \\
\text { problem in ES sessions. }\end{array}$ & 41.6 & 27.3 & 13.0 & 15.6 & 2.6 \\
\hline $\begin{array}{l}\text { 28. Pupils depend on each other for help during practical } \\
\text { activities. }\end{array}$ & 46.8 & 31.2 & 16.9 & 3.9 & 1.3 \\
\hline 31. Pupils work individually during practical activities. & 7.8 & 5.2 & 20.8 & 22.1 & 44.2 \\
\hline 32. Pupils allowed doing some experiments on their own. & 16.9 & 11.7 & 23.4 & 13.0 & 35.1 \\
\hline $\begin{array}{l}\text { 33. Pupils work co-operatively during ES practical } \\
\text { activities. }\end{array}$ & 54.4 & 32.5 & 7.8 & 3.9 & 1.3 \\
\hline $\begin{array}{l}\text { 38. Grasp of science related concepts through use of the } \\
\text { lecture method. }\end{array}$ & & 0.0 & 22.1 & 27.3 & 46.8 \\
\hline
\end{tabular}

Note: $\mathrm{VO}=$ very often; $\quad \mathrm{O}=$ often; $\quad \mathrm{SO}$ = sometimes; $\quad \mathrm{S}=$ seldom; $\quad \mathrm{AN}=$ almost never

Responses are reported as percentages of respondents.

Attitude towards use of learning materials, Table 6.

About $74 \%$ of student teachers believed that practical activities were essential even when ES concepts were well explained because practical activities enforce understanding and theory alone does not fully develop a pupil's intellectual ability. Close to 64\% of the student teachers indicated that they found apparatus for practical activities difficult to use because college lecturers did not explain how they were used. This limitation on the part of lecturers has also been observed by Buchholz, Mukwirimba and Shumba (1997) who indicated that some lecturers lack basic experience and skills. They are not clear on what materials are needed to support the teaching of ES and there are no structured induction procedures into primary college teaching for new lecturers. Some lecturers use predominantly lecturedemonstration methods because they deal with large groups of 80-130 students and concentrate too much on teaching content. Shumba (1999) also revealed that, in all regions of Zimbabwe, student teachers require support in syllabus interpretation, concept analysis, using varied methods of pupils' work, using the environment as a laboratory and as a source of materials, and using a variety of activity-based methods such as problem posing, experimentation, simulation, games, field trips, and project method. Thus, some of the student teachers' difficulties might be due to how they are taught at college, and the economic constraints at schools also add to the problems. For example, 95\% of the student teachers indicated that they relied on the demonstration method so that pupils will, at least, see something since time and equipment are usually not sufficient to allow pupils to do experiments on their own. Some of them supported use of appropriately improvised learning aids to alleviate the problem of lack of equipment, thus consistent with Pafunwa (1972), Shymansky (1978) and Kasambira (1993) who advocated for the use of learning aids which are appropriate and relevant to the background and needs of the pupils; promote hands-on activities; and take into account pupils' cultural and individual diversities and experiences. 
Table 6. Effect of learning materials on attitude $(\mathrm{N}=77)$

\begin{tabular}{llllll}
\hline Question & AS & AM & U & DM & DS \\
\hline $\begin{array}{l}\text { 13 ES practical activities are not needed when concepts are } \\
\text { well explained. }\end{array}$ & 18.2 & 5.2 & 2.6 & 13.0 & 61.0 \\
\hline $\begin{array}{l}\text { 15. ES practical activities are useless if ES syllabus is to be } \\
\text { completed }\end{array}$ & 6.5 & 5.2 & 1.3 & 16.9 & 70.1 \\
\hline 16. Find a lot of apparatus difficult to use. & 9.1 & 13.0 & 14.3 & 27.3 & 36.4 \\
\hline 18. Cannot see the point of doing many practical activities. & 2.6 & 3.9 & 2.6 & 20.8 & 70.1 \\
\hline
\end{tabular}

Note: $\mathrm{AS}=$ agree very strongly; $\mathrm{AM}=$ agree mildly; $\mathrm{U}=$ undecided; $\mathrm{DM}=$ disagree mildly; $\mathrm{DS}=$ disagree strongly.

Responses are reported as percentages of respondents.

\section{Student teachers' frequency of use of ES learning materials, Table 7.}

The frequency at which student teachers use ES learning materials in their teaching is low because the materials are not readily available, coupled with the fact that $19.5 \%$ of them find it difficult to prepare or use equipment. The majority of them (76.6\%) say that in the few occasions that they do practical work, the pupils have to share equipment, otherwise $79.2 \%$ of the time the practical activities will be in the form of demonstrations and $29.9 \%$ have often failed to do practical work due to lack of equipment. Thus, although $96.1 \%$ believe that ES activities facilitate pupils' understanding of ES theory, hands on activities are unknown in their classes.

Table 7. Frequency student teachers use ES learning materials $(\mathrm{N}=77)$

\begin{tabular}{|c|c|c|c|c|c|}
\hline Question & VO & $\mathbf{O}$ & SO & $\mathbf{S}$ & AN \\
\hline 26. ES practical equipment and material readily available. & 15.6 & 13.0 & 41.6 & 16.9 & 13.0 \\
\hline $\begin{array}{l}\text { 29. Teacher demonstrates activities during practical } \\
\text { activities }\end{array}$ & 59.7 & 19.5 & 15.6 & 3.9 & 1.3 \\
\hline 30. Failed to do practical work due to lack of equipment & 19.5 & 10.4 & 32.5 & 19.5 & 18.2 \\
\hline $\begin{array}{l}\text { 35. Pupils have to share equipment during ES practical } \\
\text { activities }\end{array}$ & 57.1 & 19.5 & 18.2 & 1.3 & 3.9 \\
\hline 36. Find it difficult to prepare or use equipment. & 5.2 & 14.3 & 33.8 & 24.7 & 22.1 \\
\hline 50. ES activities facilitate my understanding of ES theory. & 81.8 & 14.3 & 2.6 & 1.3 & 0.0 \\
\hline
\end{tabular}

Note: $\mathrm{VO}=$ very often; $\mathrm{O}=$ often; $\quad \mathrm{SO}=$ sometimes; $\quad \mathrm{S}=$ seldom; $\quad \mathrm{AN}=$ almost never Responses are reported as percentages of respondents.

\section{Interviews with college lecturers}

The seven lecturers concurred that applied education was taught in mass lectures where, very often, not even practical demonstrations were given. The time allocated to applied education, one and half hours per week per group, is not sufficient to properly cover the techniques for ES. The lecturers believed that emphasis should be placed on the use of the local environment in order to help learners appreciate the importance of the environment. The lecturers associated the lack of implementation of theory acquired prior to the teaching practice period to inadequate resources, coupled with poor local support, for example, poor cooperation from local schools' headmasters and mentors who do not allow student teachers to use the local environment. The lecturers identified other problems such as students' failure to interpret the ES syllabus; the students' lack of creativity in connection with the improvisation of teaching aids; the lack of financial resources in the majority of rural schools 
which led to apathy at the schools, resulting in insufficient aids for group work for the large classes (sometimes as many as 65 pupils) and failure to pretest activities and experiments by the student teachers. The inability to provide relevant teaching materials and the insufficient time allocated to ES practical activities also contributed to failure by student teachers to focus activities during teaching. The lecturers complained that student teachers rarely used the local environment in their lessons and did not encourage the development of positive attitudes among pupils. They attributed this to student teachers' insufficient knowledge about ES educational attitudes and blamed some of the lecturers themselves for overloading the students with too much content resulting in student teachers memorizing facts at the expense of developing scientific skills. They also lamented that the ES department did not have meaningful control over what happens during Local Teaching Practice at the college.

They acknowledged that the student teachers appeared to attempt to do their work properly, for example, they made follow-ups when their pupils were engaged in group discussions. The student teachers also showed positive attitude and interest on what pupils do by giving correct responses, marking pupils' written work, exercising good class control during ES lessons and verbally encouraging pupils to do their corrections on time and marking that work. However, the student teachers' efforts were hampered by the classes which are too large for individual attention. The majority of lecturers suggested that the college should (a). make more use of the environmental distance education related to assignments; (b). encourage the use of the environment and peer education as much as possible. (c). observation during teaching practice should include at least one lesson in which the student teacher uses the local environment for teaching; (d). demand evidence of the use of the environment during teaching practice visits; (e). continue to assist student teachers to use higher order questions in order to ensure that pupils think in a logical manner; (f). assist student teachers on improvisation and use of planned outdoor activities; (g). recommend to the college to assign $25 \%$ of coursework to positive attitude development in pupils as part of student assessment and (h). the college to encourage optimum development of the learners' observation skills.

\section{Interview with mentors}

10 of the 12 mentors admitted that they did not have sufficient knowledge and skills to adequately supervise student teachers because of the absence of regular staff development workshops on student teachers' mentorship both at college and at the schools. The unavailability of textbooks caused them to engage on drilling methods to meet the requirement of the schools' curriculum which places emphasis on examinations. 10 mentors indicated that headmasters emphasized on high pass rate but were silent on meaningful learning. They said that the local environment was not used often because it was considered time wasting since it was possible to pass grade 7 examinations without doing ES practical activities (apparently ignoring the fact that this project arose from the low pass rate which might have been caused by failure to include practical activities in teaching ES). Further, mentors did not promote use of the environment because pupils were difficult to control whilst they were outside the classroom. They also indicated that the overloaded primary school curriculum, the length of the ES scheme and the headmasters' emphasis on quantity as opposed to quality forced them to dwell on methods that allowed them to deliver as much content as possible. The headmasters needed a written exercise once per week, one exercise was given per week. The length of the ES period depended on pupils' understanding and there was little adherence to the 30-minutes long ES shown on the official time table.

Ten mentors said that the mentor's potential to assist the student teacher was limited because (a) some mentors' scientific backgrounds were too poor to enable them to conduct 
good ES lessons which the student teacher needed to imitate; (b) the shortage of resources compelled the mentor to resort to 'chalk and talk' method; (c) the mentor faces difficulty in use of ES terms; and (d) attempt to teach some mentors to adapt to new ways of teaching was met with resistance because there was no incentive given to mentors for upgrading their knowledge.

All twelve mentors agreed that (a) mentors should allow student teachers to organize use of the local environment with their classes; (b) competent mentors in ES should be encouraged to help student teachers who lack teaching aids and knowledge of the concepts to be taught; (c) on going assistance should be rendered to students teachers on how to use ES skills, activity based methods, teaching and learning aids, and (d) incentives should be organized to motivate mentors to upgrade their scientific skills.

\section{Interviews with headmasters}

Two headmasters were interviewed in Mutasa District (Premier and Bonda Schools) and one in Chipinge District (Charuma School). The headmasters indicated that there was bunching of ES topics, with few practical activities and most topics were theoretically taught. ES lesson time was not meaningfully used and that there were very few meaningful student teacher supervisions by headmasters.

The headmasters complained of lack of resources in the schools, and problems of indiscipline whenever ES lessons are conducted in the local environment. Such inhibiting factors forced most student teachers to dwell heavily on theory and use of picture cuttings in place of locally available materials. Student teachers deliberately ignored improvisation in ES lessons and only targeted on main examination points. One headmaster remarked that some student teachers were lazy and gave meaningful ES lessons only when they were assessed by lecturers, headmasters, teacher in charge, and class mentors. Some of them hate to teach ES because it is not their favourite subject. This attitude by some of the student teachers caused most pupils to show little interest in learning ES. Pupils were found to be withdrawn from what was going on, and seem not to be interested in mastering the key points in ES lessons. The headmasters suggested that most headmasters should be staff developed on how to use the local environment as a laboratory since some still believe that all learning should take place in the classroom. They should also upgrade their knowledge of ES from time to time.

\section{Lesson observations}

Four lesson observations were carried out at four schools. The student teacher at Murahwa Hill School, Mutare urban, had the topic: "Some grasses are crop plants" The one at Pafiwa School, Mutasa District, had "The three states of water can be changed", at Muradzikwa School, Zimunya District, the topic was "Dirty water can be filtered to make it clean", and at Goko School, Chipinge District, the topic was "Some substances can make water dirty”. All student teachers used predominantly lecture-discussion and demonstration methods, teaching large groups of 45-55 pupils. They exhibited very little motivation and little understanding of ES concepts. However, the classroom environment and climate were satisfactorily conducive for learning. Pupils worked in groups of 6-10, did not ask questions but were quiet or communicating in Shona most of the time although the theoretical development of ES skills such as observation was good.

Three of the four student teachers had problems with the language of ES and appeared to view learning as memorizing facts and could not design experiments. The student at Muradzikwa High School was the only one who meaningfully improvised the apparatus for the observed lesson. The lessons were largely content laden and theoretical, consistent with 
Shumba (1999) who observed that "the majority of schools had pupils who just knew many facts but did not know anything to do with them".

\section{Documents}

A total of 20 exercise books were picked at random in each of the classes observed. The written work was predominantly of the type that promotes low order skills: filling in the blank spaces and drawing of diagrams, and no experimental-write ups. Pupils' written exercises indicated that pupils just copied everything and could not relate the information to everyday application situation.

All the 4 student teachers' schemes of work and the detailed lesson plans were perfectly written and capable of promoting positive ES attitude development. It was, however, not possible to tell the extent of their effectiveness for attitude change, consistent with Bogdan and Biklen (1992) who noted that pupils' classroom written records reflect, to a large extent, how much was taught and learnt, although it may not necessarily guarantee that there has been change of attitudes towards a subject.

\section{Intervention strategies}

Student teachers (33\%) indicated that the mentors coach them on how to acquire positive attitudes alongside learning new things. However, 10 of the 12 mentors admitted that their potential to assist the student teacher was limited by their scientific backgrounds which were too poor to enable them to conduct good ES lessons which the student teachers needed to imitate and they, thus, did not have sufficient knowledge and skills to adequately supervise student teachers. The headmasters admitted that they needed to be staff developed on matters related to ES.

The lecturers know the problems students meet on teaching practice. They should not only concentrate on theory, but should also assist student teachers on improvising teaching aids and on practicing how to conduct ES lessons. It is not enough for the lecturers to associate the lack of implementation of theory acquired prior to the teaching practice period to inadequate resources, coupled with poor local support, for example, poor cooperation from local schools' headmasters and mentors who do not allow student teachers to use the local environment. They should assist student teachers go around the problems. The lecturers identified other problems such as students' failure to interpret the ES syllabus; the students' lack of creativity in connection with the improvisation of teaching aids. But, surprisingly, even their recommendations are silent on these two most pertinent issues. Lecturers should go beyond identifying problems which have been reported before (Pafunwa, 1972; Shymansky, 1978; Kasambira, 1993; Buchholz, Mukwirimba and Shumba, 1997; Shumba, 1999) and, instead, assist students to solve their problems. Future research should focus on whether significant attitude difference exists between male and female student teachers.

\section{Conclusion}

The study revealed that discussion, lecture, group and demonstration (the drilling methods) are still used quite often by student teachers. Very few experiments and little use of the environment as a laboratory when teaching ES were being done in most ES lessons. Pupils work in large groups and individuals were not accorded the opportunity to make discoveries on their own. Most schools did not have sufficient ES equipment and teaching aids and the majority of student teachers did not have the ability to improvise teaching aids, were not skilled enough to handle large groups of pupils and did not have proper knowledge about ES educational attitudes. They tended to emphasize on content in most ES lessons, leading to 
memorization of facts at the expense of scientific skills. Most headmasters want all learning to take place in the classroom and have no respect on the use of the local environment as a laboratory. They could conveniently upgrade their knowledge about ES during staff development workshops which take place at schools and at the college. Improvement of the preparedness of Headmasters and mentors should enhance the chances of student teachers to get proper assistance so that they emerge from their teaching practice having gained substantially in the correct teaching of ES. Learners' positive attitude towards science could be enhanced by teachers' enthusiasms, resourcefulness and helpful behaviour, teachers' thorough knowledge of the subject matter and their making science interesting to learn (Ernest, 1988; Yara, 2009). Thus, the low pass rate suffered by Grade 7 candidates might be due to lack of preparedness on the part of the teachers. By their own submission, some of the Grade 7 teachers, the mentors, admitted to being unable to give model lessons which student teachers could emulate. The failure rate could be blamed on the teaching methods employed in the schools.

\section{References}

Ary, D., Jacobs, L. C. and Razavich, A. (1990). Introduction to Research in Education. London: Holt, Rinchart and Winston, Inc.

Ausubel, D. P. (1963). The Psychology of Meaningful Verbal Learning. New York: Grune and Stratton.

Ausubel, D. P. (1968). Educational psychology: A cognitive view. New York: Holt, Rinehart \& Winston.

Best, W. \& Khan, J. V. (1993). Research in Education. Boston: Allan and Bacon.

Bogdan, R. C. \& Biklen, S. K. (1992). Qualitative Research for Education: An Introduction to Theary and Methods. Boston: Allyn and Bacon.

Borg, R. W. \& Gall, M. D. (1983). Educational Research. London: Longman.

Buchholz, J., Mukwirimba, A. \& Shumba, O. (1997). Situational Analysis on Primary Teacher Preparationfor Environmental Science Education in Zimbabwe and Proposals for Suport. Better Environmental Science Teaching Programe (BEST). Harare and Frankfurt: Curriculum Development Unit (CDU) \& Deutsche Gesellschft fur Technische Zusamamenarbeit (GTZ).

Chivore, B. R. S. (2005). A Situational Evaluation (Analysis) of the Implementation of Education for All in Zimbabwe. Harare: University of Zimbabwe.

Chikuni, B. (2005). Action Research in Teaching Education. Harare: Flame Printers.

Ernest, P. (1988). The attitudes and practices of student teachers of primary school mathematics, (in A. Borbas Ed. Proceedings of 12th International Conference on the Psychology of Mathematics Education, Hungary, July 1988, Volume 1, Veszprem, Hungary, OOK.: 288-295.)

Gall, M. D., Borg, W. R., \& Showers, J. P. (1996). Educational Research: An Introduction ( $6^{\text {th }}$ Ed.). New York: Longman.

Gatawa, B. S. M. (1990). The Politics of the School Curriculum. Harare: College Press.

Gay, L. R. (1996). Educational Research: Competences for Analysis and Application..New Jersey: Prentice Hall. 
Gay, L. R. (1996). Educational Research: Competences for Analysis and Application..New Jersey: Prentice Hall.

Kasambira, K. P. (1993). Teaching Methods. Harare: College Press.

Kyriacou, C. (1986). Effective Teaching in Schools. Cheltenham: Basil Blackwell Ltd.

Lincoln, Y. S. \& Guba, E. G. (1985). Naturalist Inquiry. London: Sage Publications

MaCleod, J. (2000). An Introduction to Counselling. Buckingham: Philadelphia Open University.

Magagula, C. M. (1995). The Issue of Paradigms in Educational Research: Keeping the Debate Alive. Zimbabwe Journal of Educational Research. ......

Majasan, J. A. (1995). The Teacher Profession: A Manual for Professional Excellence. Ibadan: Spectrum Books Limited.

Marshall, C.\& Rossman, G. B. (1999). Designing Qualitative Research. 2rd Ed. California: Sage Publications Ltd.

Matsikidze, A. A. (1994).Attitudes Towards Science Laboratory Work: An Exploratory Surveyof Both Secondary Students and Science Teachers in Chimanimani District Schools. Harare: University of Zimbabwe.

Mhlanga, E. \& Ncube, N. J. (2003). Research Methods and Statistics. Harare: Zimbabwe Open University.

Novak, J. D. (2000). Meaningful learning: The essential factor for conceptual change in Limited or Inappropriate Propositional Hierarchies (LIPHs) leading to empowerment of learners, jdn2@gte.net, Cornell University. (2000). Retrieved 27 February, 2009

Nyawaranda, V. (1997). Doing a Qualitative Research Study. Zimbabwe Bulletin of Teacher Education. University of Zimbabwe.

Pafunwa, A. B. (1972). Why Teach Physics. In Lewis J. L. (Ed.), Teaching School Physics. A UNESCO Resource Book. London: UNESCO.

Shumba, O. (1997). Monitoring Findings on the Better Environmental Science Teaching Programme (BEST) in Primary Schools and Teacher Training Colleges in Zimbabwe. Harare: Curriculum Development Unit (CDU) and Technical Co-operation of Germany (GTZ).

Shumba, O. (1998). Monitoring Findings on the Better Environmental Science Teaching Programme (BEST) in Primary Schools and Teacher Training Colleges in Zimbabwe. Harare: Curriculum Development Unit (CDU) and Technical Co-operation of Germany (GTZ).

Shumba, O. (1999). Report on the 1999 BEST Monitoring in Phase 1 Regions and the Situation Analysis in Phase 11 Regions. Harare: Curriculum Development Unit (CDU) and Technical Co-operation of Germany (GTZ).

Shymansky, J. A. (1978). How Teaching Strategies Affect Students: Implication for Teaching Science. In M. B. Rowe (Ed). What Research Says to the Science Teacher. Pp 40-54, vol 1, National Science Teacher Association.

Simpson, R. D. (1978). Relating Students Feelings to Achievement in Science. In M. B. Rowe (Ed). What Research Says to the Science Teacher. Pp 40-54, vol 1, National Science Teacher Association. 
Stenhouse, L. (1975). An introduction to Curriculum Research and Development. Oxford: Heimmann Education Books Ltd.

Worthen, B. R. \& Sanders, J. R. (1987). Educational Evaluation: Alternatives Approaches and Practical Guidelines. New York: Longman.

Yara, P. O., (2009). Relationship between Teachers' Attitude and Students' Academic Achievement in Mathematics in Some Selected Senior Secondary Schools in South Wstern Nigeria, European Journal of Social Sciences - Volume 11, Number 3, 364 369.

Yin, R. K., (1989). Case Study Research: Design and Methods. Newbury: Longman.

\section{APPENDICES}

Appendix 1. Guidelines for Lecturer Interview.

1. How can student teachers' attitude towards use of practical activities to teach ES be improved?

2. What problems will student teachers face when implementing your suggestions?

3. What problems do student teachers face when developing practical activities?

4. Do student teachers (a) use or (b) make reference to the environment?

5. What science attitude encouragements do student teachers make when teaching?

6. Describe how students show (a) love, (b) care and (c) interest in what pupils do?

7. What can be done to make sure that student teachers implement hands-on minds-on activities as demanded by the ES syllabus?

Appendix 2. Guidelines for Interviews with Mentors.

1. (a) Does the student teacher enjoy ES hands-on minds-on activities?

(b) What are the indicators for such enjoyment?

(c) What may cause failure to enjoy hands-on minds-on activities?

2. (a) Does the student teacher use apparatus when teaching ES?

(b) How often?

(c) What problems does the student teacher face?

3. (a) Is the student teacher convinced about the importance of doing experiments with pupils?

(b) Can you justify your reasoning?

4. What does the student teacher do to indicate looking forward to ES practical lessons?

5. Does the student teacher enjoy supervising pupils during ES practical activities?

6. How do large numbers of pupils affect pupils' mastery of concepts?

7. (a) How often does the student teacher demonstrate activities during ES lessons?

(b) Which concepts warrant use of the demonstration method?

8. How often do pupils do experiments and what problems are experienced?

9. What was covered in the staff development workshop on improvement of ES teaching?

10. Do pupils read written instructions before they do a practical exercise?

11. What size of groups does the student teacher assign pupils for group work?

12. To what extent do ES practical activities enhance preparation of pupils for final examinations?

13. In what ways do you help the student teacher to make pupils like ES?

14. What constraints student teachers as they try to develop positive ES attitudes in pupils?

15. What are your indicators for success in the ability to develop positive attitude in the pupils? 
Appendix 3. Guidelines for Interview with Headmasters.

1. How do you get funding for ES practical activities?

2. (a) Do you staff develop student teachers on ES teaching and learning?

(b) How do you make sure that recommendations are implemented?

3. How do attitude problems affect the way pupils learn ES?

4. How can the student teacher be assisted to develop interest in teaching ES?

5. Do student teachers use the local environment (LE) for teaching purposes?

6. What problems do the student teachers face in connection with the use LE as a lab?

Appendix 4. Guidelines for use during Lesson Observation.

1 a) Did the teacher show motivation for the subject and topic?

b) Did the pupils seem to be interested in the lesson?

c) Did the pupils understand what they were doing?

d) Were pupils' activities related to the environment?

e) Is the classroom environment conducive for learning?

f) Is the classroom climate conducive for learning?

g) Did the teacher encourage pupils to ask questions?

2. Indicate the techniques the student teacher used during the ES lesson by ticking from the list below:

a) lecturing to pupils without visualization.

b) explaining, using chalk board or other visualization.

c) asking questions.

d) answering pupils' questions.

e) reading to pupils.

f) showing something to the pupils.

g) demonstrating something to the pupils.

h) involving pupils in carrying out an experiment.

i) assigning group or individual work to pupils.

j) supervising group or individual.

k) leaving the class to use the environment to explain or demonstrate something.

l) making apparatus with the pupils using materials from the environment.

3. Open questions and comments.
a) Describe how the teacher made use of the environment during the lesson.
b) Which skills did pupils develop during the lesson?
c) Did the teacher plan for these skills?
d) Comment on the number of pupils who appear to have developed the skills.
e) Which attitudes (persistence, curiosity, humility, open mindedness, tolerance skeptics, co-operation and objectivity) are being developed?
f) Do pupils' written answers show evidence of the development of these skills?
g) Did the pupils seem to enjoy use of the developed ES skills?
Did learners use the ES attitudes to answer the work assigned to them by the teacher?
f) Were there the other strong points in the lesson?

Appendix 5. Some of the points raised in the student teacher's questionnaire (Routine questions have been omitted to save space). 
Indicate how you agree with the following statements in the following boxes VS=very strongly, $\mathrm{S}=$ strongly, $\mathrm{U}=$ undecided, $\mathrm{DM}=$ disagree mildly, DS= disagree strongly. Then in (b) explain your choice.

\section{For example}

\begin{tabular}{llllll}
\hline Question & VO & O & SO & S & AN \\
\hline 100. I work with kids very well & & & & & \\
\hline
\end{tabular}

(b) Why?

If you strongly agree, tick under VO which means very often, if you just often do so, tick in box under $\mathrm{O}$ which means often, if you sometimes do so, tick in box under SO which means sometimes, if you seldom do so, tick in box under $S$ which means seldom, or if you almost never do so, tick in box under AN which means almost never.

Then in line (b) Give your reason(s) for making that choice.

11. (a) I enjoy teaching ES. (b). Why?

12. (a) I like spending more teaching ES even if it means working after hours. (b). Why?

13. (a) When explanation is done well, there practical activity may be left out. (b). Why?

14. (a) ES practical activities should be done only with slow learners. (b). Why?

15. (a) ES practicals are useless if the syllabus is to be completed. (ba). Why?

16. (a) I find a lot of apparatus difficult to use. (b). Why?

17. (a) ES activities do more harm than good. (b). Why?

18. (a) I do not see the point of doing many practical activities. (b). Why?

19. (a) I always look forwards to ES practical sessions. (b). Why?

20. (b) All one has to do learn in a scientific manner is to study writings of great scientists.

(b) Why?

21. (a) ES activities are too involving and I enjoy discussion sessions to practical sessions.

(b) Why?

22. (a) I get round the whole class during ES practical activities. (b). Why?

23. (a) I enjoy supervising fast learners during ES practical activities. (b). Why?

24. (a) Our regular ES sessions are not related to practical activities. (b). Why?

25. (a) Our ES class is crowded when we are doing practical activities. (b). Why?

26. (a) The equipment and materials needed for ES practical activities are readily available.

(b) Why?

27. (a) In our ES sessions different pupils collect different data for same problem. (b) Why?

28. (a) Pupils are able to depend on each other for help during practical activities. (b). Why?

29. (a) The teacher demonstrates activities during practical activities. (b). Why?

30. (a) We have failed to do practical work due to lack of equipment. (b). Why?

41. (a) I cannot see the point of doing many experiments. (b). Why?

42. (a) The classroom is hot and stuffy. (b). Why?

43. (a) The teacher provides clear instructions during ES practical activities. (b). Why?

44. (a) There is opportunity for pupils to pursue their own science interesting our ES practical work. (b). Why?

45. (a) I use group ES practical work. (b). Why?

46. (a) It is difficult to organize ES practical work in the period allocated. (b). Why?

47. (a) ES practical work hardly enhances acquisition of concepts learnt during theory lessons.

(b) Why?

48. (a) ES practical work enables pupils to be able to design experiments to investigate problems.

(b) Why? 
49. (a) ES practical work enhances pupils' preparation for final exams. (b). Why?

50. (a) ES practical work facilitates my understanding of science theory. (b). Why?

51. (a) I find a lot of ES apparatus difficult to use. (b). Why?

52. (a) Pupils prefer to do experiments on their own, not in groups. (b). Why?

53. (a) I feel like I am in prison when I am involved in any form of ES practical work.

(b) Why?

54. (a) I assist pupils who have different cultural values and beliefs to grasp ES concepts. (b). Why? 